\title{
Analisis Efektifitas dan Efisiensi Retribusi Pedagang Kaki Lima di Kota Parepare
}

\author{
Yadi Arodhiskara $^{1}$, Zulkarnain ${ }^{2}$ \\ ${ }^{1,2}$ Universitas Muhammadiyah Parepare
}

\section{INFO NASKAH}

Diserahkan

10 September 2017

Diterima

16 Oktober 2017

Diterima dalam revisi

30 November 2017

Diterima dan disetujui

4 Desember 2017

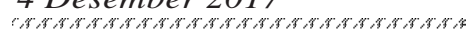

\section{Kata Kunci:}

Efektifitas

Efisiensi

Pendapatan daerah

Retribusi daerah

Pedagang kaki lima

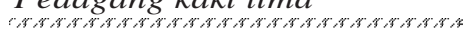

Kode Klasifikasi JEL:

O10

012

\begin{abstract}
ABSTRAK
Tujuan penelitian ini adalah menganalisis efektifitas dan efisiensi retribusi pedagang kaki lima di Kota Parepare. Penelitian ini dilakukan dengan pendekatan positivism yang menekankan pada kombinasi antara logika deduktif dan penggunaan alat-alat kuantitatif dalam menginterpretasikan suatu fenomena secara objektif. Hasil penelitian menunjukkan bahwa potensi penerimaan yang bersumber dari pedagang kaki lima setiap bulannya mencapai Rp21.879.000 atau setiap tahunnya Rp262.548.000. Jumlah pedagang kaki lima menunjukkan peningkatan yang signifikan menjadi 187 orang dengan tingkat efektifitas yang sangat tinggi yakni berada pada angka rata-rata $100 \%$ atau $158,53 \%$ capaian penerimaan retribusi pedagang kaki lima. Hal ini didukung dengan efisiensi yang baik dalam pengelolaan biaya pemerolehan yang hanya mencapai $2,04 \%$ dari penerimaan pedagang kaki lima. Peta potensi teridentifikasi pada 3 (tiga) zona yang merupakan wilayah sebaran pedagang kaki lima di Kota Parepare.
\end{abstract}

\section{Pendahuluan}

Sistem pengelolaan keuangan pemerintahan di Indonesia untuk mendukung pembangunan pada awalnya menerapkan sistem sentralisasi namun setelah lahirnya Undang-Undang Nomor 32 kemudian direvisi menjadi Undang-Undang Nomor 23 Tahun 2014 tentang Pemerintahan Daerah yang menjadi sistem pemerintahan Indonesia menjadi desentralisasi. Sistem ini telah memperluas wewenang pelaksanaan otonomi daerah dengan menyerahkan sepenuhnya segala urusan pemerintahan kepada pemerintah daerah. Salah satu kewenangan yang diberikan pada daerah yaitu kewenangan dalam menggali dan mengolah pendapatan daerah. hal ini sesuai dengan Undang-Undang Nomor 23 tahun 2014 yang menyatakan pendapatan daerah adalah 
semua hak daerah yang diakui sebagai penambah nilai kekayaan bersih dalam periode tahun tahun anggaran yang bersangkutan.

Kemandirian keuangan yang dimiliki pemerintah daerah dapat meningkatkan kemampuan daerah untuk membiayai urusan rumah tangganya sendiri. Kemampuan tersebut berupa penggalian dan pemobilisasian sumber-sumber pendapatan daerah yaitu Pendapatan Asli Daerah (PAD) (Iskandar, 2013). Retribusi merupakan sumber penerimaan daerah yang cukup potensial di daerah, dalam rangka meningkatkan kemandirian daerah maka pelaksanaan dalam mengelolahnya perlu dikembangkan secara efektif dan efisien. Setiap daerah dapat berkreatifitas dalam peningkatan retribusi daerah untuk kesejahteraan masyarakat.

Penerimaan daerah harus didukung oleh tingkat efektifitas. Halim (2008) menyatakan bahwa efektifitas adalah kemampuan pemerintah daerah dalam merealisasikan Pendapatan Asli Daerah yang direncanakan dibandingkan dengan target yang ditetapkan berdasarkan potensi ril daerah. Efektifitas terkait antara hasil yang diharapkan dengan hasil yang sesungguhnya dicapai (Mahmudi, 2015). Faktor lain yang menggambarkan penerimaan retribusi semakin baik adalah tingkat efisiensi suatu jenis penerimaan retribusi. Menurut Mahmudi (2015) efisiensi terkait dengan hubungan antara output berupa barang atau pelayanan yang dihasilkan dengan sumber daya yang digunakan untuk menghasilkan output tersebut. Sementara Halim (2008) menyatakan bahwa efisiensi adalah rasio yang menggambarkan perbandingan antara besarnya biaya yang dikeluarkan untuk memperoleh pendapatan dengan realisasi pendapatan yang diterima.

Beberapa penelitian sebelumnya menunjukkan eratnya keterkaitan antara efektifitas dan efisiensi dengan penerimaan retribusi daerah. Murniati dan Kasasih (2017) meneliti tentang kontribusi dan efektifitas penerimaan retribusi pelayanan pasar terhadap Pendapatan Asli Daerah Kota Palembang. Hasil penelitiannya menunjukkan bahwa tingkat efektifitas retribusi pasar dari tahun 2011 sampai dengan 2015 mengalami kenaikan dan penurunan antara periode tersebut. Penelitian yang dilakukan oleh Ramlan (2015) mengenai efektifitas dan potensi retribusi pedagang kaki lima terhadap Pendapatan Asli Daerah di kota Makassar periode 2009-2013, menunjukkan bahwa efektifitas retribusi pedagang kaki lima di Kota Makassar bersifat sangat efektif.

Kota Parepare sebagai kota niaga dan jasa, perekonomiannya didukung berbagai sektor namun yang paling dominan sektor perdagangan sehingga banyak bertumpu pada UMKM (Usaha Menengah Kecil dan Mikro) diantaranya pedagang kaki lima yang menjadi potensi 
besar bagi penerimaan daerah. Tahun 2012 Pendapatan Asli Daerah sebesar Rp67 miliar, tahun 2013 Pendapatan Asli Daerah sebesar Rp84,9 miliar dan tahun 2014 Pendapatan Asli Daerah sebesar Rp75,1 miliar. (www.pareparekota.go.id). Kota Parepare sedang dalam tahap pembangunan dan dikenal sebagai kunjungan untuk wisata kuliner sekaligus menarik pengusaha dari luar daerah untuk membangun usaha kuliner di kota ini. Banyaknya pasar dan pedagang kaki lima menjadi potensi pembangunan yang menciptakan peluang terbukanya pekerjaan. Sehingga dari potensi pekerjaan itu bisa kembali dalam bentuk retribusi ke penerimaan daerah.

\section{Metode Penelitian}

\subsection{Pendekatan Penelitian}

Penelitian ini menganalisis efektifitas dan efesiensi penerimaan retribusi pedagang kaki lima di Kota Parepare. Penelitian ini dilakukan dengan pendekatan kuantitatif atau biasa disebut positivism, yaitu pendekatan yang menekankan pada kombinasi antara logika deduktif dan penggunaan alat-alat kuantitatif dalam menginterpretasikan suatu fenomena secara objektif (Efferin dkk., 2008:35). Pendekatan ini diharapakan dapat menjelaskan fenomena yang ada berdasarkan data dan fakta yang ada di lapangan. Penelitian ini dilakukan pada pemerintah daerah Kota Parepare khususnya Dinas Pendapatan Daerah kota Parepare; Dinas Koperasi; dan Usaha Mikro Kecil dan Menengah kota Parepare.

\subsection{Variabel Penelitian}

Variabel penelitian ini adalah efektifitas dan efisiensi retribusi pedagang kaki lima, diukur dengan menggunakan rasio efektifitas dan efesiensi penerimaan retribusi daerah.

\subsection{Metode Analisis Data}

Analisis data yang digunakan dalam penelitian ini adalah analisis potensi, efektifitas dan efisiensi.

a. Analisis Potensi

Analisis perhitungan potensi mutlak diperlukan dalam analisis menetapkan target rasional. Dengan potensi yang ada, setelah dibandingkan penerimaan untuk masa yang akan datang, maka akan didapatkan besarnya potensi terpendam, sehingga akan dapat diperkirakan rencana tindakan apa yang akan dilakukan untuk menggali potensi yang tersebut untuk 
menentukan berapa besarnya rencana penerimaan yang akan datang. Cara menghitung potensi retribusi pedagang kaki lima adalah sebagai berikut (Prakosa, 2005):

Potensi Retribusi PKL $=($ Jumlah PKL) $\mathrm{x}$ (Tarif) $\mathrm{x}($ Waktu/Hari $)$.

\section{b. Analisis Efektifitas}

Rasio Efektifitas digunakan dalam mengukur tingkat efektivitas dari penerimaan retribusi Pedagang Kaki Lima (PKL) di Kota Parepare, dengan formulasi penerimaan Pendapatan Asli Daerah (Mahmudi, 2010):

\section{$\frac{\text { Realisasi Penerimaan Retribusi } P K L}{\text { Target Penerimaan Retribusi } P K L} X 100 \%$}

Nilai Efektifitas dapat dikategorikan sebagai berikut:
1) Sangat Efektif
: > $100 \%$
2) Efektif
$: 100 \%$
3) Cukup Efektif
: $90 \%-99 \%$
4) Kurang Efektif
: $75 \%-89 \%$
5) Tidak Efektif
$:<75 \%$

c. Analisis Efisiensi

Rasio Efisiensi digunakan dalam mengukur tingkat efisiensi dari penerimaan retribusi pedagang kaki lima,formulasi yang digunakan adalah Rasio Efisiensi Pendapatan Asli Daerah (Mahmudi, 2010):

\section{$\frac{\text { Realisasi Pemerolehan Retribusi PKL }}{\text { Target Pemerolehan Retribusi PKL }}$ X 100\%}

Nilai efisiensi dapat dikategorikan sebagai berikut:
1) Sangat Efisien
$:<10 \%$
2) Efisien
: $10 \%-20 \%$
3) Cukup Efisien
$: 21 \%-30 \%$
4) Kurang Efisien
: $31 \%-40 \%$
5) Tidak Efisien
: $>41 \%$ 


\section{Hasil dan Pembahasan}

\subsection{Hasil}

\section{Potensi Retribusi Pedagang Kaki Lima}

Berdasarkan hasil analisis potensi retribusi pedagang kaki lima (PKL) di Kota Parepare, diketahui bahwa jumlah potensi retribusi pedagang kaki lima sebesar Rp21.879.000 perbulan atau dalam setahunnya mencapai Rp262.548.000. Besaran potensi tersebut didasarkan atas temuan lapangan yang mengakumulasikan sebanyak 187 pedagang kaki lima secara ril membayar retribusi selama periode tahun 2016. Sesuai data yang didapatkan menunjukkan potensi retribusi pedagang kaki lima masih memiliki peluang kontribusi yang cukup besar dalam meningkatkan Pendapatan Asli Daerah (PAD).

\section{Jumlah Pedagang Kaki Lima}

Data lapangan yang diperoleh menunjukkan sebanyak 187 pedagang kaki lima yang tersebar pada 18 tempat atau lokasi di Kota Parepare. Lokasi PKL berjualan terbanyak berada di Pasar Senggol dengan 35 pedagang dan Jl. Bau Massepe sebanyak 33 pedagang sementara di Jl. A. Sinta hanya ada 1 orang pedagang kaki lima.

\section{Tingkat Efektivitas dan Efisiensi Retribusi Pedagang Kaki Lima}

Berdasarkan hasil pengolahan data, maka dapat diketahui bahwa rata-rata tingkat efektivitas penerimaan retribusi pedagang kaki lima selama 3 (tiga) tahun terakhir dari tahun 2012 sampai dengan 2014 rata-rata persentase efektifitasnya sebesar 158,53\%, dimana pada tahun 2012 penerimaan retribusi pedagang kaki lima sebesar 162,94\%, pada tahun 2013 penerimaan retribusi pedagang kaki lima sebesar 205,69\%, pada tahun 2014 penerimaan retribusi pedagang kaki lima sebesar 106,96\%. Hasil tersebut dapat diklasifikafikan tingkat efektifitasnya sangat efektif meskipun dalam periode tersebut terjadi fluktuasi penerimaan retribusi namun masih di atas $100 \%$.

Tingkat efisiensi retribusi pedagang kaki lima didasarkan atas hasil pengolahan data menunjukkan bahwa rata-rata tingkat efisiensi penerimaan retribusi pedagang kaki lima selama 3 (tiga) tahun dari tahun 2012 sampai dengan 2014 sebesar 2,04\%. Pada tahun 2013 tingkat efisiensi retribusi pedagang kaki lima sebesar 1,69\% mengalami tingkat yang lebih baik dibandingkan tahun sebelumnya dan pada tahun 2014 tingkat efisiensi retribusi pedagang kaki lima mengalami sedikit perubahan menjadi 1,88\%. Tingkat persentase mengalami 
fluktuasi dalam kurun waktu 3 (tiga) tahun. Hal ini tidak menyebabkan terjadinya perbedaan kategori tingkat efisiensi setiap tahunnya, dikarenakan masih berada pada kisaran tingkatan kategori sangat efisien.

\section{Peta Potensi Pedagang Kaki Lima}

Peta potensi pedagang kaki lima disusun berdasarkan sebaran pedagang kaki lima yang tersebar pada 4 (empat) kecamatan. Hasil identifikasi menunjukkan sebaran lokasi yang digunakan pedagang kaki lima tersebar pada 18 lokasi. Berdasarkan sebaran tersebut, disusun zona sebagai salah satu poin dalam perumusan baru tarif retribusi pedagang kaki lima selain tarif standar yang hanya mengenakan ukuran luas permeter tempat yang digunakan oleh para PKL di Kota Parepare.

\subsection{Pembahasan}

\section{Potensi Retribusi Pedagang Kaki Lima}

Data yang dimiliki oleh Dinas Pendapatan Daerah Kota Parepare menunjukkan target yang direncanakan sebesar Rp187.148.000. Setelah dianalisis menunjukkan masih tingginya potensi retribusi pedagang kaki lima. Hal ini ditunjukkan dengan meningkatnya jumlah pedagang dari data sebelumnya yaitu sebanyak 187 PKL dengan potensi penerimaan perbulannya sebesar Rp21.879.000 atau dalam setahunnya mencapai Rp262.548.000. Potensi peningkatan memberikan ruang bagi pemerintah daerah untuk memperbesar target penerimaan retribusi yang berasal dari pada pedagang kaki lima. Penelitian ini sejalan dengan penelitian yang dilakukan oleh Ramlan (2015), dimana dalam penelitiannya menunjukkan bahwa setiap tahunnya potensi retribusi pedagang kaki lima terus meningkat.

\section{Jumlah Pedagang Kaki Lima}

Data lapangan menunjukkan terjadi peningkatan jumlah pedagang kaki lima dari sebelumnya hanya 70 meningkat menjadi 187 PKL. Peningkatan jumlah pedagang kaki lima di tahun 2016 memberikan gambaran iklim usaha di Kota Parepare masih dapat dikembangkan lagi khususnya di sektor usaha kecil dan menengah. Sebaran pedagang kaki lima saat ini tidak hanya terpusat lagi di perkotaan tapi juga sudah tumbuh di pinggiran kota. Hal ini terlihat dengan adanya 24 pedagang kaki lima di Kecamatan Bacukiki dan 4 (empat) di Kecamatan Bacukiki Barat, dimana selama ini kedua kecamatan tersebut jauh dari pusat kota. 
Perkembangan pedagang kaki lima tidak hanya akan berkontribusi terhadap peningkatan Pendapatan Asli Daerah (PAD), tapi juga akan mendorong tumbuhnya pusat ekonomi baru dan menciptakan lapangan kerja alternatif bagi masyarakat Kota Parepare.

\section{Tingkat Efektivitas dan Efisiensi Retribusi Pedagang Kaki Lima}

Tingkat efektivitas retribusi dalam kurun waktu 3 tahun 2012-2014 menunjukkan ratarata penerimaan berdada di atas $100 \%$ atau $158,53 \%$ dan dikategorikan sangat efektif. Tingkat efektifitas yang sangat tinggi ini dapat memberikan keyakinan kepada Pemerintah Daerah Kota Parepare untuk meningkatkan target penerimaan retribusi dengan memperluas atau membuka ruang yang lebih banyak kepada pedagang kaki lima. Peningkatan target akan mendorong kreatifitas instansi terkait dalam memenuhi target atau di atas target tersebut. Jika pada periode 2012-2014 retribusi PKL hanya ditargetkan rata-rata Rp120.045.666,67 pertahunnya, maka dengan potensi penerimaan yang mencapai Rp262.548.000 pertahunnya akan mudah bagi pemerintah daerah memenuhi target tersebut. Temuan ini sesuai dengan penelitian yang dilakukan Ramlan (2015) yang menunjukkan sangat efektifnya penerimaan retribusi yang bersumber dari PKL.

Pada tingkat efisiensi menunjukkan bahwa dalam periode 2012-2014, efisiensi dari penerimaan retribusi sangat baik rata-rata berada pada kisaran 2,04\%. Hal ini menunjukkan bahwa jenis retribusi pedagang kaki lima mampu menekan biaya pemerolehannya sangat rendah dengan kontribusi yang cukup tinggi. Kemampuan tersebut akan memberikan jaminan bagi pemerintah daerah untuk meningkatkan PAD melalui penambahan petugas pungut atau peningkatan insentif agar para petugas dapat lebih memperluas daya jangkaunya dalam melakukan pemungutan retribusi.

\section{Peta Potensi Pedagang Kaki Lima}

Peta potensi pedagang kaki lima merupakan satu tawaran bagi pemerintah daerah untuk menambahkan item tersebut masuk dalam rumus penentuan tarif retribusi pedagang kaki lima. Peta ini didasarkan atas zona masing-masing yang memiliki tarif retribusi sendiri dengan indikator zona yang terdekat dengan pusat kota akan memiliki nilai pasar atau tarif yang lebih tinggi dibandingkan dengan zona lainnya. Peta potensi terbagi atas 3 (tiga) zona yang ditawarkan, yaitu zona 1, 2, dan 3. Penentuan zona didasarkan pada sebaran pedagang kaki lima yang memiliki akses lebih cepat dengan pusat kota. Zona tidak membatasi pada wilayah 
tertentu, tapi atas potensi kontribusi terbesar diberikan pada penerimaan pendapatan daerah.

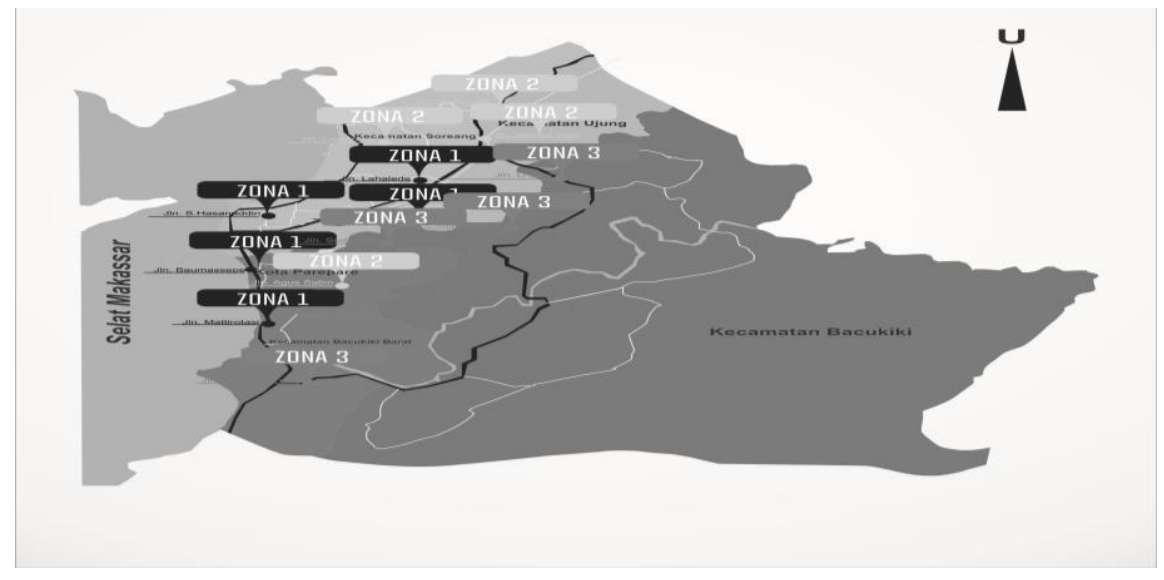

Gambar 1. Peta Zona Retribusi Pedagang Kaki Lima di Kota Parepare

Penambahan item zona dalam penentuan tarif retribusi selain akan menambah kenaikan PAD juga akan memberikan keadilan bagi PKL yang lokasinya berjauhan dengan pusat kota, namun pengenaan tarif yang diberikan sama.

\section{Simpulan dan Saran}

Tujuan penelitian ini adalah menganalisis efektifitas dan efisiensi retribusi pedagang kaki lima di Kota Parepare. Berdasarkan hasil penelitian yang dilakukan, maka beberapa kesimpulan dalam penelitian ini adalah: potensi penerimaan pedagang kaki lima sebesar Rp21.879.000 perbulan atau Rp262.548.000 pertahunnya; jumlah pedagang kaki lima sebanyak 187 orang di tahun 2016; tingkat efektifitas berada pada angka rata-rata 100\% atau 158,53\%; dan peta potensi menunjukkan 3 (tiga) zona yang merupakan wilayah sebaran pedagang kaki lima di Kota Parepare.

Penelitian ini memiliki keterbatasan yaitu menggunakan data belanja langsung dan tidak langsung setiap SKPD terkait dengan retribusi daerah. Penelitian selanjutnya diharapkan lebih mendalam dan fokus pada upaya pemerintah daerah memperoleh retribusi daerah tidak hanya pada satu wilayah saja agar hasilnya dapat digeneralisasi pada wilayah lainnya.

\section{Daftar Pustaka}

Efferin, S., S.H. Darmaji, dan Y. Tan. 2008. Metode Penelitian Akuntansi: Mengungkap Fenomena dengan Pendekatan Kuantitatif dan Kualitatif. Yogyakarta: Graha Ilmu.

Halim, A. dan M. Iqbal. 2012. Pengelolaan Keuangan Daerah Seri Bunga Rampai Manajemen Keuangan Daerah. Yogyakarta: UPP STIM YKPN. 
Halim, A. 2015. Akuntansi Keuangan Daerah. Jakarta: Salemba Empat.

Iskandar, N. 2013. Analisis Penerimaan Retribusi Daerah dan Pajak Daerah Serta Kontribusinya Terhadap Pendapatan Asli Daerah Kota Parepare. Skripsi. Fakultas Ekonomi Universitas Muhammadiyah Parepare.

Mahmudi. 2010. Analisis Laporan Keuangan Pemerintah Daerah. Yogyakarta: UPP STIM YKPN.

Mahmudi. 2015. Manajemen Kinerja Sektor Publik. Edisi Ketiga. Yogyakarta: UPP STIM YKPN.

Mardiasmo. 2005. Akuntansi Sektor Publik. Yogyakarta: Andi.

Mardiasmo. 2013. Perpajakan. Edisi Revisi 17. Yogyakarta: Andi.

Masyarakat Sebagai Pelaku Ekonomi. http://www.gerbangilmu.com. Diakses tanggal 23 Februari 2016.

Murniati, S. dan D. Kasasih. 2017. Analisis Kontribusi dan Efektifitas Penerimaan Retribusi Pelayanan Pasar Terhadap Pendapatan Asli Daerah Kota Palembang. Jurnal Kompetitif, 6 (1): 85-109.

Prakosa, K.B. 2005. Pajak dan Retribusi Daerah. Yogyakarta: UII Press.

Ramlan, M. N. 2015. Analisis Efektivitas dan Potensi Retribusi Pedagang Kaki Lima Terhadap Pendapatan Asli Daerah di Kota Makassar Periode 2009-2013. Skripsi. Universitas Hasanuddin Makassar.

Realisasi APBD Tahun 2012 sampai tahun 2014 Kota Parepare. http://www.pareparekota.go.id. Diakses tanggal 2 Februari 2016.

Republik Indonesia. Peraturan Menteri Dalam Negeri Nomor 59 Tahun 2007 Tentang Pedoman Pengelolaan Keuangan Daerah.

Republik Indonesia. Peraturan Menteri Dalam Negeri Nomor 13 Tahun 2006 Tentang Pedoman Pengelolaan Keuangan Daerah.

Republik Indonesia. Undang-Undang Republik Indonesia Nomor 23 Tahun 2014 Tentang Pemerintahan Daerah.

Republik Indonesia. Undang-undang Republik Indonesia Nomor 28 Tahun 2009 Tentang Pajak Daerah dan Retribusi Daerah.

Republik Indonesia. Undang-undang Republik Indonesia Nomor 9 Tahun 1995 Tentang Usaha Kecil. 